\title{
ABSTRACT \\ The Transnationalism of Swedish and Russian National Theatres in the Second Half of the Eighteenth Century: How Foreign Performative Art Sharpened the Aesthetics of National Identity
}

In this article, I consider the formation of national theatres in Sweden and Russia under the guidance of King Gustav III and Empress Catherine II. Both Swedish and Russian theatres in the second half of the eighteenth century consolidated their nationalism by appealing to various national cultures and absorbing them. One of the achievements of the Enlightenment was the rise in popularity of theatre and its transnationalism. Several European countries, like Russia, Sweden, Poland, Hungary and others, decided to follow France and Italy's example with their older traditions, and participate in the revival of the theatrical arts, while aiming at the same time to preserve their national identities. The general tendency in all European countries of "second theatre culture" was toward transnationalism, i.e. the acceptance of the inter-penetration between the various European cultures with the unavoidable impact of French and Italian theatres. The historical plays of the two royal dramatists - Gustav III and Catherine II - were based on national history and formulated following models of mainly French and English drama.

The monarchs resorted to the help of French, Italian and German composers,

stage designers, architects, choreographers and actors to produce their plays. However, such cooperation only emphasized Swedish as well as Russian nationalism. Despite many similarities, Gustav III and Catherine II differed somewhat in how each positioned their own brand of nationalism. By delving deeper into the details of the formation of the national theatres by these monarchs, I will explore similarities and differences between their two theatres.

Keywords: Gustav III, Catherine II, Swedish eighteenth-century theatre, Russian eighteenth-century theatre, national theatre, transnationalism, mobile artists.

BIOGRAPHY

Maria Berlova is a lecturer in European Art History at the Russian University of Theater Arts (GITIS, Moscow, Russia). She also works as a Senior Researcher at the State Institute for Art Studies. Right now she is working on two book projects: Performing Power. Political Masks of Gustav III in English and Theater of the King in Russian. Berlova received her MA in theater studies at GITIS in 2006, and PhD in 2011. She obtained her second PhD from Stockholm University in 2013. Her research interests are European theater history of the eighteenth century, particularly Swedish and Russian theater history. mashaberlova@yandex.ru 


\section{The Transnationalism of Swedish and Russian National Theatres in the Second Half of the Eighteenth Century How Foreign Performative Art Sharpened the Aesthetics of National Identity}

\section{MARIA BERLOVA}

Both Swedish and Russian theatres of the second half of the eighteenth century consolidated their nationalism by appealing to various national cultures and absorbing them. One of the achievements of the Enlightenment was the rise in popularity of theatre and its transnationalism. The openness of national cultures and their exposure to mutual influence in the eighteenth century favoured an ease of communication and a nomadism of ideas across geographical and cultural boundaries, factors which played important roles in the development of the theatre of the period. ${ }^{1}$ The French and Italian theatres, with comparatively older traditions, were especially influential in Europe. In the second half of the eighteenth century several European countries, like Russia, Sweden, Poland, Hungary and others, decided to follow France and Italy's example and participate in the revival of the theatrical arts, while aiming at the same time to preserve their national identities. The general tendency in all European countries of "second theatre culture" was toward transnationalism, i.e. the acceptance of inter-penetration between the various European cultures with the unavoidable impact of French and Italian theatres. Thus the nationalism of culturally developing countries in the age of Enlightenment had a pan-European legacy source with contemporary tendencies.

In this article, I intend to study the phenome- non of the formation of national theatres in Sweden and Russia under the guidance of King Gustav III, who reigned from 1771 to 1792, and Empress Catherine the Great, who reigned from 1762 to 1796. The similarity between the two monarchs is not only in being cousins, but also in that both were playwrights and builders of their national theatres. ${ }^{2}$ The individual histories of the two monarch-playwrights' processes of creating the Swedish and Russian national theatres are rather similar from the perspective of the transnationalism of their national cultures. The historical plays of the two royal dramatists were based on national history and formulated following models of mainly French and English drama. Both Gustav III and Catherine II resorted to the help of French, Italian and German composers, stage designers, architects, choreographers and actors. Thus, the cultural nationalism of both monarchs was a by-product of international collaboration. However, such cooperation only emphasized Swedish as well as Russian nationalism. Its consolidation was in fact the result of an assimilation of various national cultures. Despite many similarities, Gustav III and Catherine the Great differed somewhat in how each positioned their own brand of nationalism. Gustav III was more eager to form a national theatre in Swedish, while the Russian version in the hands of Catherine the Great was far more open to foreign companies performing in their 
native-languages: Italian or French. Nevertheless, the Russian Empress felt a greater concern for the originality of national identity in her plays than her Swedish cousin. By delving deeper into the details of the formation of the national theatres by these monarchs, I will explore further similarities and differences between their two theatres.

First, consider the national theatre of Gustav III. Similar to his mother Queen Lovisa Ulrika (172082), Gustav had been passionate about theatre since childhood. As a youngster Gustav acted in court performances and later, as a king, he took on the role of a performer both on the court stage as well as in his politics. Theatre often appeared at crucial moments in Gustav's life. On March 1, 1771 in the midst of a performance at the Opera in Paris, Gustav was informed his father had died and that he was now King of Sweden. In 1792, Gustav was assassinated at the masquerade at the Opera in Stockholm, as immortalized by Giuseppe Verdi's opera Un ballo in maschera (A Masked Ball).

In August 1772, Gustav carried out a bloodless coup d'état aimed at the centralization of royal power where he successfully performed his role of monarch by referring to his kingly predecessors Gustav Vasa (1496-1560) and Gustav II Adolph (1594-1632). Five months later, in January 1773, the Swedish Opera was established and his inauguration took place in Bollhuset or "The Ball House" which was built in 1627 for ball sports and later used as a theatre.

From the very beginning Swedish opera was an international enterprise. Although the language of the country's first national opera, Thetis och Pelée (Thetis and Peleus), was Swedish, the opera itself was modelled on a French one, a strategy which later became characteristic of Gustavian theatre. The genre of the opera - tragédie lyrique - was typically French. The Sun King was an immutable model for the Swedish King, who even openly borrowed French court rituals. Thus, as a model for the first national opera, Gustav III chose a performance from the time of Louis XIV, the mythological opera Thetis and Peleus of 1689, with the text by Bernard Le Bovier de Fontenelle and the music by Pascal Collasse. Thetis, a half nymph, and Peleus, an ordinary mortal, fall in love. However, their happiness is endan- gered because Peleus has two serious rivals, the gods Jupiter and Neptune. In the finale, the betrothal between Thetis and Peleus is celebrated on Olympus. ${ }^{3}$ Swedish poet Johan Wellander put Gustav's libretto into rhyme, but the composer and conductor of the opera was Italian, Francesco Uttini (1723-95). Uttini performed with the Italian company in Stockholm in 1750 and thereafter stayed on and actively worked in Sweden for the rest of his life. Despite his Italian training, the composer had to follow the French model of tragédie lyrique, which had five acts with song and dance divertissements at the end of each act. The ballet scenes in the opera were staged and rehearsed by Louis Gallodier (ca. 1734-1803), a French ballet dancer and choreographer, who stayed on in Stockholm after the French company was dismissed by Gustav III in 1771 because the King wanted to cut down on expenses and promote the national theater. Gallodier spent the majority of his career in Sweden, where he had a great influence on the development of the ballet in Sweden as master of the Royal Swedish Ballet. In accordance with the genre of tragédie lyrique, the opera Thetis and Peleus abounded in spectacular scenic effects. As a model for the scenery, Gustav chose examples of French scenery from the seventeenth century, for instance that of Jean Berain. Thus, the first Swedish national opera was national only in that it was presented in the Swedish language (not Italian or French) and featured Swedish singers and dancers. Also, a Swedish twist in this opera was that Gustav III deviated from the French model by presenting Neptune as a good lord, which made for a transparent parallel with the mild king Gustav III. But from all other perspectives, the opera was a synthesis of French and Italian theatrical arts. ${ }^{4}$ To understand the real significant difference between Gustavian musical theatre and that of Catherine the Great it must be remembered that the main genre in Russian of that time was not tragédie lyrique, but opéra comique; this genre was performed both by foreigners and native artists.

Internationalism in Swedish national opera only increased with time. The prevalent form of Swedish opera was French, with dance as a significant element and emphasis on the visual effects. Recent updates and news of Parisian opera were constant- 
ly offered to the King by Swedish diplomats at the embassy. They regularly sent Gustav III detailed reports, librettos and drawings of costumes. ${ }^{5}$ It is worth noting that besides French tragédie lyrique, which was aesthetically close to baroque theater, the new trends in opera also reached Sweden. In 1773, Gluck's Orpheus and Eurydice was performed in Stockholm, which had had its premiere in Paris only a year earlier. That same year Handel's Acis and $G a$ latea was also staged and another opera by Gluck, Iphigenia in Tauris, was performed in 1778.

Who were the foreigners who traveled to Sweden and whose cultural background enriched the Swedish National Theater? Besides Gallodier, Gustav invited another French choreographer and ballet dancer, Antoine Bournonville (1760-1843), the father of the famous August Bournonville. Antoine Bournonville was the premier dancer and ballet instructor at the Royal Swedish Opera in Stockholm from 1782 until 1792. He was also active as an actor, singer and choreographer. During his stay in Sweden he wrote the ballets Les Meuniers provençaux (1785) and Les Pêcheurs (1789).

In 1783-84, Gustav III embarked on a long journey that took him to Italy. This enterprise, historically known as the Italian Journey of Gustav III, was of significant importance to Swedish culture. The King was inspired to create a forum for ancient sculpture in Sweden. With this purpose in mind, he purchased a number of sculptures and other art objects that laid the foundation for the Royal $\mathrm{Mu}$ seum, established after Gustav III's death in 1792. The collection is preserved today as Gustav III's Museum of Antiquities. The Italian journey of Gustav III also had an impact on his theater because during his visit the King encountered Louis Jean Desprez (1737-1804). This French artist and architect, who at that time worked in Italy, was hired to become a stage designer of Gustav III's opera and drama performances. Desprez moved to Sweden and actively worked there until Gustav III's death. After 1792 Desprez lost his popularity and died destitute in Stockholm in 1804 . The stage scenery of Desprez as well as dramas by Gustav III can be attributed to pre-romanticism. Desprez's misty and mysterious landscapes, architectural structures and interiors were known to be extremely impressive and pic- turesque. Among his productions are Gustav III's Queen Christina and Gustav Vasa: the latter was a triumphal success. ${ }^{6}$

Besides French choreographers and a French stage designer, there were also foreign composers who greatly contributed to the formation of the Swedish National Theater. French opera music was not in favor in late eighteenth century Europe. Therefore composers were brought to Stockholm initially from Italy and later Germany. The German composers who worked in Sweden were Johann Gottlieb Naumann (1741-1801) and Joseph Martin Kraus (1756-92). In 1777, Naumann, a composer, conductor and Kapellmeister from Dresden, was appointed to reform the Stockholm Hovkapell (Court Choir) and assist King Gustav III in his opera plans. His most famous opera works were the 1782 production of his opera Cora och Alonzo at the inauguration of the new Opera house in Stockholm and the 1786 production of Gustav Vasa.

Kraus moved to Sweden at age 22 and died at the age of 36 in Stockholm. He is often called "the Swedish Mozart". His big success was the opera Proserpina with its libretto by Gustav III, which the poet Johan Henric Kellgren versified. The opera premiered successfully at Ulriksdal Palace on 6 June 1781. Kraus was appointed vice-Kapellmeister of the Royal Swedish Opera and director of the Royal Academy of Music. In order for him to learn more about theater, Gustav III sent Kraus on a Grand Tour of Europe lasting five years. Kraus was an innovative composer and conductor. Besides music for theater, he wrote many symphonies and concertos and much chamber music. Although he was best known for writing stage music, his greatest work, Aeneas in Carthage, remained unperformed during his lifetime. For the theatrically staged funeral of Gustav III, Kraus wrote a funeral cantata and the Symphonie funèbre, which were played at the burial ceremony on April 13, 1792.

Georg Joseph Vogler, also known as Abbé Vogler (1749-1814), a German composer, organist, teacher and theorist, also worked in Sweden. Although Vogler is mostly known as an experimenter in baroque and early classic music, he also wrote both sacred music and operas. His major piece for theater was the opera Gustav Adolf och Ebba Brahe, based 
on Gustav III's play and staged in 1788. Vogler also founded a music school in Stockholm in $1786 .^{7}$

During the 1780s, after the Swedish National opera was formed, Gustav III formed the National drama theatre in the Swedish language. However, the King's first step toward the formation of a Swedish drama theatre had been controversial and caused displeasure amongst the Swedish nobility. In 1771 Gustav III had dismissed the French troupe of his parents in order to form the national theater, but ten years later, through the Swedish ambassador in Paris, he hired another French troupe led by Jacques-Marie Boutet de Monvel (1745-1812), the playwright and eminent actor of the ComédieFrançaise. In the beginning, Monvel's troupe consisted of 16 members, who performed for royalty in the court theaters. Beginning in 1783 the troupe also regularly performed for the general public in Ballhuset. The repertoire of the troupe was mostly French classical drama, as well as Voltaire, Claude Prosper Jolyot de Crébillon, Michel-Jean Sedaine, Monvel, Philippe Néricault Destouches, Denis Diderot, Pierre-Augustin Caron de Beaumarchais and others. The model for Monvel was Lekain, the favorite actor of Voltaire. Thus, Monvel brought Lekain's acting style to Sweden. A passionate actor and a true master of declamation, Monvel taught a whole generation of young Swedish actors. Gustav III worried that Monvel would run away from Sweden and had the police guard him, but even that didn't work because in 1787 Monvel got permission to travel to France and never returned. With the death of Gustav III in 1792, the French troupe ceased to perform in Stockholm. ${ }^{8}$

Although Gustav III involved French actors in the process of forming the national dramatic theatre, his main goal as King was to create a national repertoire in the Swedish language. In order to achieve this, Gustav III himself wrote and produced plays in Swedish. Thus, the King became the main playwright of his time and founding father of both the national theatre and the national dramatic repertoire. In 1788, Gustav III founded the Dramatic Theatre (Dramaten). Gustav's Swedish national drama serves as a great example of transnationalism and illustrates how nomadic the ideas of theatre were in his time. French plays, for instance those by Voltaire, Charles Collé, Baculard d'Arnaud and others, inevitably served as a model for the King. According to Marie-Christine Skuncke, all Swedish drama of Gustav's time can be defined as a Franco-Swedish hybrid, but it should also be noted that there were other influences on Swedish drama such as Italian, Spanish, English, Danish and German. Usually, non-French drama was accessible in French translations. ${ }^{9}$ However, in spite of the borrowed French form, Gustav's plays were filled with Swedish content. Thus, Gustav's dramas were based on Swedish history and the great Swedish kings and queens such as Gustav Vasa, Gustav II Adolph and Queen Christina, all main characters of some of his plays. ${ }^{10}$

As a great example of the truly national character of multi-cultural Gustavian theatre, let me mention Gustav III's play Gustav Vasa, which was turned into rhyme by the Swedish poet Johan Henric Kellgren and staged as an opera in 1786. Alexis Piron's French drama Gustave (1733) and Henry Brooke's Irish tragedy Gustavus Wasa (1739) had an impact on Gustav III's play. Gustav Vasa was based on national history: the liberation of Sweden from Denmark in the beginning of the sixteenth century. The opera's language was Swedish, but the composer, Johann Gottlieb Naumann, was German. Its scenery was designed by French artist Louis Jean Deprez. Its choreographer was also the Frenchman Louis Gallodier. The leading roles were performed by Swedes, Carl Stenborg and Kristofer Kristian Karsten as well as the Danish opera singer Carolina Müller. The collaboration of international artists resulted in an enormous success. The captivating music in the tradition of Gluck was considered Naumann's best piece. It was perceived as highly patriotic and even today remains well-known in Sweden. Deprez' scenery was also stunning and the performance abounded in captivating stage effects. Despite the international character of Gustav Vasa, it was considered a national opera. The nationalism of Gustav Vasa was not only due to the history on which the opera was based, but also the striking correspondence between the theme taken from national history and contemporary events. According to Erik Lönnroth, Gustav III was preparing to go to war against Denmark at that time. ${ }^{11}$ In the 
context of the political events, the opera became a powerful instrument of royalist propaganda in that it strengthened national consciousness and caused an incredible rise of patriotism among Swedes. (As we will see, contemporaneous examples (although maybe not on the same scale) of multicultural national musical performances similar to Gustav Vasa can be found in the Russian theatre of Catherine the Great, in that the Empress also enlisted foreigners to produce her plays.)

Paradoxically, in other productions of Gustav III, international tendencies only strengthened Swedish nationalism. For instance, in 1790, during the war between Sweden and Russia (1788-90), Gustav III anonymously staged his play Alexey Mikhailovich and Natalia Narishkina, which glorified the Russian Tsar Alexey Mikhailovich, the father of Peter the Great. The play was staged as a musical comedy with songs and dance. Alexey Mikhailovich, based on a historical anecdote, is about the Russian Tsar who married Natalia Narishkina, despite the fact that she was from an impoverished noble family and brought up in a village. The Tsar preferred her innocence and spontaneity to the stuffiness and ceremoniousness of the court ladies. In the way that Gustav III represents these ladies during a review of eventual brides at the palace, one can see a satire on contemporary morals. In 1789, while the King was writing this play, the attitude of the nobility towards him was extremely bellicose because of its displeasure with the policies of the Monarch and especially the Russian-Swedish war. By directing his satire at the court ladies, the King was retaliating against the opposition of the upper classes. Thus, the parallels between the events of Russian history and Gustavian Sweden made the play fit into the National Swedish repertoire. There was also another reason why this play, glorifying the Russian Tsar during the Russian-Swedish war, actually served to glorify the Swedish National theatre. By staging Alexey Mikhailovich, Gustav III wanted to show, for the first time in the history of the Swedish theatre, the luxurious Russian-style costumes and decorations on the stage of Dramaten. ${ }^{12}$ Thus, Gustavian theatre consolidated its nationalism by appealing to various national cultures and absorbing them. The Russian Empress did the same, though she would not praise a Swedish king in her drama during the war with Sweden. Actually, she did quite the opposite, as we will see later in the discussion of Catherine's play about Gustav III.

The process of forming the national theatre in Russia was rather similar to what occurred in Sweden, although even more complex. Compared to a poor Sweden, Russia was a prosperous empire which had many opportunities to import theatrical arts from Western Europe. In his article About Russian Theatre of Non-Russian Origin and Non-Russian Structure, ${ }^{13}$ Nikolai Evreinov, the Russian theatre practitioner, theorist and historian who worked at the beginning of the twentieth century, claims that Russian theatre is not original and that, "it is not only of non-Russian origin, but it also doesn't have any original Russian structure". ${ }^{14}$

According to Evreinov, the Russian theatre is the product of foreign culture and was imitative of it throughout almost its entire history. Although Evreinov's idea may be questioned, it obviously deserves attention. From the perspective of a non-Russian original and a non-Russian structure, Evreinov traces the history of Russian theatre from its origin to the beginning of the twentieth century. I will adduce some of Evreinov's arguments and supplement them with my own so that the situation of the Russian theatre at the time of Catherine the Great will become clear.

In Russia, the first theatre performance was organized by the well-educated Johann Gottfried Gregory (1631-75), a German pastor of the Lutheran church sent to Moscow as a Saxon elector. Gregory, with the help of other Germans (Georg Hübner, his translator, and Lorenz Ringuber, his stage director), organized the production in Western European style on July 4, 1672, during the reign of Aleksey Mikhalovich (1645-76). During the reign of Peter the Great (1682-1721), Gregory's successor was Johan Christian Kunst and after him Otto Fürst, both of whom were German. The performances were also mainly in German. At the time of Peter the Great, some Russian plays were written but were simple imitations of Western European ones, Jesuit school dramas and French miracle and morality plays. During the reign of Peter the Great's successors, until the reign of Catherine the 
Great, the foreign troupes working in Russia were the German troupes of I.-G. Mann, a commedia dell' arte troupe from Italy, Friederike Caroline Neuber's troupe from Leipzig (from 1740 to 1742), Charles De Sérigny's troupe from France (from 1742), the German troupe of Konrad Ernst Ackermann (from 1747 to 1752 ), and the Giovanni Battista Locatelli troupe from Italy (from 1757 to 1762). Mikhail Lomonosov, the famous Russian scientist and poet, wrote his tragedies Tamara and Selim (1750) and Demophon (1751) under the influence of Nicolas Boileau-Despréaux's Art poétique, which was translated into Russian. Finally, the Russian National Theatre was founded on August 30, 1756, during the reign of Elisabeth from 1741 to 1762 . Alexander Sumarokov, a prominent Russian playwright, became the director of the Russian Theatre. He was highly inspired by the French classical theatre and Jean-Baptiste Racine in particular. Jakov Kniazhnin, another Russian playwright of this time, imitated and translated Pierre Corneille, Jean-Baptiste Racine and François Voltaire, even though his intention was to create a theatre to depict everyday Russian life.

Just like the Russian playwrights, the first Russian actors were also heavily influenced by foreign theatre as in Gustavian Sweden. Fyodor Volkov, known as the first Russian actor, had Melissino and Osterwald as his teachers. Volkov also became an admirer of Konrad Ernst Ackermann and adopted his acting style. Ivan Dmitrevsky, another eminent Russian actor of that epoch, fell under the influence of Lekain and David Garrick, whom he saw during his journeys abroad. The biggest influence on Russian actors was Jean-Aufresne-Rival, an actor of the Comédie-Française whose acting style was considered simple and natural, who broke away from the classical style prevailing in France at that time and had to move to Russia in 1785 where he performed and taught.

In contrast to Sweden, where the Frenchman Desprez was in charge of scenery and costumes, in Russia, costumes and scenery were produced by Italians. An example of this is Giuseppe Valeriano, a follower of Ferdinando Galli Bibiena, who in scenery construction replaced the central (vertical) axis with a diagonal axis, introducing an angular perspective along the diagonal.

Catherine the Great's reign was the time of the development of the national theatre and it became possible thanks to Western European theatrical art. The plays of Catherine the Great serve as a great example of significant Western European influence, just as her cousin's plays do. Her comedy Oh, These Times! was modelled on the comedy Die Beschwester by Christian Fürchtegott Gellert, the German poet. The Empress' comedy This 'tis to have Linen and Buck-Baskets is an imitation of Shakespeare's The Merry Wives of Windsor, just as her historical plays The Life of Rurik and The Initial Period of Oleg's Reign were written in imitation of Shakespeare's chronicle plays. Other Russian playwrights of that period followed the example of the Empress. The play Brigadier, written by Denis Fonvisin, the famous Russian playwright, has as a model Jean de France by Ludvig Holberg, the Danish playwright. Moreover, Fonvisin's comedy Young Ignoramus has an obvious relationship with French neoclassicism. According to Evreinov, the rest of the Russian playwrights at that time were at best compilers and at worst copycats. ${ }^{15}$ However, not everyone agrees with Evreinov as I will attempt to demonstrate later. Nevertheless, one has to admit the fact that there was an obvious predominance of translated and imitative plays over the original ones.

If Russian drama developed under the influence of French drama, Russian opera and ballet were highly influenced by Italian theatrical art. In 1735-38, during the reign of Anna Ioannovna from 1730 to 1740 , an Italian troupe dominated in Russia. Francesco Domenico Araja was a composer and Antonio Rinaldi, known as Fossano, was a choreographer of this troupe. There were certain efforts made to stage Russian operas, but stage directors and composers were Italians, as for instance in the Russian opera Cephalus and Prokris with music by Francesco Araja and a libretto by Alexander Sumarokov (the language was Russian), staged in 1755.

Although Italians brought ballet to Russia, its further development was influenced by Frenchmen. At the same time as Fossano, his rival Jean-Baptiste Landé, the French choreographer, worked in Russia. 
It was he who opened the first ballet school in St. Petersburg in 1738, known today as the Vaganova Ballet Academy. In 1759, Franz Hilverding, the Austrian choreographer, came to Russia. He is considered to be the predecessor of Jean-George Noverre, the creator of ballet d'action. In 1766, Hilverding was succeeded by Gaspare Angiolini who attempted to introduce elements of Russian culture into his own work through the use of songs, folk dances and Russian themes. After this came Giuseppe Canziani and then Charles le Picq, who subsequently introduced Noverre's ballet to Russia.

In eighteenth-century Russia, even theatre buildings were constructed on the initiative of foreigners. Unlike Sweden, where the new building of the Royal Opera by the Swedish architect Carl Fredrik Adelcrantz opened in 1782, the first public theatre in St. Petersburg was founded in 1783 on the initiative of Karl Knipper, the leader of the German theatrical troupe. Moreover, the public theatre in Moscow was first founded in 1758 on the initiative of Giovanni Battista Locatelli, the director of the Italian troupe. When this theatre burned down, Michael Maddox, the Jewish-English entrepreneur, founded the Petrovka theatre in 1780. Today the Bolshoi Theatre is located on its site. ${ }^{16}$

The Russian theatre building from the eighteenth century which deserves special mention and is still preserved today is the Hermitage Theatre of Catherine the Great. It was the second theatre of the Winter Palace and replaced the Russian Imperial Theatre, which operated from 1764 until 1783. Although the Hermitage Theatre was a court theatre designed for three hundred spectators who were courtiers and foreign ministers, this theatre played an important role in the formation of national theatre as the plays by Catherine the Great and many other Russian playwrights of that time had their first production there. The theatre was built from 1783 to 1789 by Giacomo Quarenghi, the famous Italian architect. The Hermitage Theatre is connected with the Hermitage by a gallery on top of the arch spanning the Winter Canal.

The internationality of the Hermitage Theatre reflected very well the theatrical situation in the country. French, Italian and Russian troupes per- formed in the Hermitage Theatre. Forming the national theatre, the Empress welcomed foreign theatrical art, as she realized that without its contribution the Russian theatre would never flourish. In the second half of the eighteenth century, the popular theatrical genre in Russia was Italian opera seria and, later, beginning in 1770, it was also opera buffa. In eighteenth-century Russia, the positions of court chapel masters were always held by Italians. At the time of Catherine the Great, these were Tommaso Traetta (from 1768 to 1776), Giovanni Paisiello (from 1776 to 1784), Giuseppe Sarti (from 1784 to 1802) and Domenico Cimarosa (from 1787 to 1791). Thus, the operas by these composers as well as the operas by Antonio Salieri and Vicente Martín y Soler were performed in the Hermitage Theatre.

Among the distinguished Italians who contributed to Russian theatrical art, one has to mention Pietro Gonzaga, the Italian stage designer, architect and theorist of art who worked in Russia from 1792 until his death in 1831. Just as Louis Jean Deprez in Sweden, Gonzaga was an innovator in stage design. His stage sets depicting architectural structures and landscapes are characteristically tinged with a romantic mood. It is not without reason that his theoretical treatise described the art of scenery painting as "music for the eye".

Although the Italian opera was popular, French comedy remained by far the most popular form throughout Catherine's rule. It significantly outnumbered Italian and Russian productions. The French troupe performed plays by such French authors as François Voltaire, Jacques-Marie Boutet de Monvel and Charles-Simon Favart. The second most frequently staged theatrical form was the Russian comedy, both original and translated. The Hermitage Theatre's Russian troupe performed the adaptations, or literal translations of the best plays by Western European dramatists, particularly French, such as by Molière, Beaumarchais, G.-B. Regnard as well as the Irishman Richard Brinsley Sheridan. In addition, plays by such Russians authors as Fonvisin, Sokolov, Yefimyev, Emin and Plavilshchikov (who were to some extent influenced by French drama), were performed in the Hermitage Theatre.

The reign of Catherine the Great is noted as an 
epoch of comic operas. The operas buffa by Paisiello, Cimarosa, Sarti and Martin-y-Soler were performed at the Hermitage Theatre. Many of the most famous Italian comic operas were produced as free translations into Russian and performed by local actors and companies. Thus, transnationalism contributed to the formation of national theatre. It is worth mentioning that it is at this time that Russian composers also appeared. ${ }^{17}$

In addition, Catherine the Great wrote plays which were staged as comic operas. The theatrical works of Catherine the Great, which were staged not only in the Hermitage Theatre but also in the public theatres of St. Petersburg and Moscow, serve as a good example of how the foreign form could have original content. I do not agree with Evreinov, who argues that the Russian playwrights of the second half of the eighteenth century, including Catherine the Great, had no originality. Just as in Gustavian Sweden, the originality of the national theatre in late-eighteenth-century Russia was born out of a synthesis of various theatrical cultures and this theatre acquired a local colour. For instance, Russians playwrights such as Vladimir Lukin and Peter Plavilshchikov wrote original plays by touching upon original Russian themes. Let me illustrate my point by using Catherine's plays.

It is known that Catherine the Great uttered the following dictum: "Theatre is the school for the people. I am the chief master in this school and I am responsible before God for the morals and manners of the people."18 Thus, Catherine's drama, which not only included comic operas, but also comedies, imitations of Shakespeare and proverbes (a French genre of a short moralizing play), had as its main purpose, besides entertaining, to educate the masses and teach them morals. That idea corresponded with French neoclassical drama, which served as the main model for Catherine as a playwright. It is worth mentioning that she also imitated Shakespeare and produced partial adaptations of plays by Calderón and Sheridan. However, despite borrowing foreign forms, Catherine succeeded in filling them with original content. The realities of her plays are very Russian. As Lurana Donnels O’Malley points out, in her numerous comedies, the Empress addresses specifically Russian concerns and audiences. "She tackles such contemporary national problems as ignorance, superstition, Gallomania, fear of progress, and anything she perceived as mysticism." 19

Catherine based her imitations of Shakespeare's historical plays on Russian history. The main characters of the Empress' plays were national heroes, similar to the historical dramas of Gustav III. For example, Catherine's main characters were Oleg, the uncle and preceptor of Prince Igor who ruled from 912 to 945, and the ruler of the Russian Kiev in The Initial Period of Oleg's Reign, and the Varangian Prince Rurik who ruled from 862 to 879, the father of Igor and the founder of the principality of Novgorod in the play The Life of Rurik.

Oleg was staged as an opera during the theatrical season of 1790-91. It was the most grandiose staging of any of Catherine's plays. The music was composed partly by the Italians Carlo Canobbio and Sarti, and partly by the Russian Vasily Pashkevich. The choreographers were Giuseppe Canziani and Charles Le Picq. Just as in the case of Gustav's Gustav Vasa, Catherine's Oleg was also an international enterprise and also had a strongly expressed national spirit. For the production, Catherine introduced old Russian ceremonies, as illustrated by the wedding between Prince Igor and Prekrasa. Also, the Empress actively participated in the design of beautiful costumes made in the old-Russian style.

What also made the production truly national was the political context. Just like Gustav III's plays, Catherine's drama was firmly inscribed in her politics. Catherine's play shows Oleg in his successful campaign against Constantinople. After he concludes a favourable peace, he is received with due honours by the Emperor Leo and Empress Zoe. It is noteworthy that during the staging of Oleg, Russia was engaged in a successful war with the Ottoman Empire (1787-91) and the patriotic feelings that the play inspired became a kind of compensation for the unrealized "Greek project" of Catherine II directed at the submission of the Ottoman Empire and the division of its territory between Russia, the Holy Roman Empire and the Venetian Republic. Catherine II contemplated the revival of the Byzantine statehood under the leadership of her grandson who was named Constantine in honour of the founder of Constantinople. 
There are many similarities between the theatres of Catherine the Great and that of her Swedish cousin. Both enlightened monarchs formed the national theatre. Both monarchs wrote plays. Both monarchs used foreign dramas as the models for their dramatic works. Moreover, both Gustav and Catherine achieved originality in their plays by appealing to national history as well as the contemporary life of the nation. Both monarchs inscribed their theatres in the political context. Both Catherine and Gustav resorted to the help of foreigners in order to create their national theatres. The cooperation of the two monarchs with foreign theatre artists sped up the formation of new national cultures: in Sweden the national theatre, opera and ballet were established in just fifteen years. Although there are many similarities between the national theatre of Gustav and that of Catherine, there are some differences as well. Catherine was not as much obsessed by the idea of the creation of the national theatre as Gustav III, who dismissed the French troupe of his parents in order to form the national theatre. The Russia of Catherine the Great abounded in foreign troupes, which performed their original repertoires. Thus, the Russian national theatre had only a modest place on the theatrical map of the country. However, the question of national identity was more acute in Russia than Sweden, where Swedish theatre, according to Skuncke, was both a national and cosmopolitan enterprise. ${ }^{20}$ This matter was very important for Catherine herself. Although Gustav III was of German stock, he was born in Sweden and considered himself a Swede, and the Swedish language was his native tongue. Catherine II, a German by birth, was born and raised in Prussia until she moved to Russia. However, Catherine considered herself Russian and she emphasized her national identity by all possible means, which is reflected in her plays. Catherine wrote her plays in Russian, with the only exception being the proverbs written in French. ${ }^{21}$ While assimilating foreign cultures, Catherine fervently advocated Russian originality. In her comedies based on French models, Catherine II mocked Gallomania, just as many other Russian playwrights of her time.

Similarly, Catherine mocked the foreigners in her comedy Prominent Nobleman's Entrance Hall
(1772). In this play, nine men and women descend upon the foyer of the nobleman Khrisanf's house, but do not get a chance to meet him, only his servants and assistants. Most of the characters are Russians, but three of them are foreign: a German, a Frenchman and a Turk. Catherine mocks their misuse of the Russian language of which she was an ardent advocate.

The focus of Catherine the playwright was always on Russian life. If she were a Swede, she would have never written an Alexey Mikhailovich and $\mathrm{Na}$ talia Narishkina, a play praising a foreign leader, as Gustav III did. When Catherine wrote Woeful Knight Kosometovich, a play about Gustav III who started the war against Russia in 1788, it was a political pamphlet against him. Although Catherine's play was about the Swedish king, the empress did not restrain from strongly expressing her nationalism. The play was based on a Russian fairy-tale, the characters were Russian and the play's language was inspired by Russian folklore.

Nevertheless, Catherine's nationalism, just as that of Gustav's, always needed international support. It was Martin y Soler, an Italian, who wrote the music for Catherine's highly nationalistic play about her Swedish cousin, which was staged as a comic opera at the Hermitage Theatre in 1789. Thus, nomadic artists contributed greatly to the formation of national theatres in Sweden and Russia, particular in shaping the aesthetics of national identity. 


\section{NOTES AND REFERENCES}

1 Dmitry Trubotchkin, "Italianskiy teatr XVIII veka" in Istoria iskusstv stran Zapadnoy Evropy. XVIII vek (Дмитрий Трубочкин, “Итальянский театр XVIII века" в Истории искусств стран Западной Европь. XVIII $в е \kappa)$, State Institute of Art Studies, Moscow, forthcoming.

2 Despite striking similarities there was an essential difference between the two monarchs. It was an additional hobby of Gustav III to be an actor of the court theater for a period of time, whereas Catherine the Great never acted on stage.

3 Marie-Christine Skuncke, "Gustaviansk teater" in $\mathrm{Ny}$ svensk teaterhistoria. 1, Teater före 1800, Tomas Forser, Sven Áke Heed, eds., Gidluns förlag, Hedemora 2007, p. 191.

4 Skuncke, op. cit., pp. 190-2; Georg Nordensvan, Svensk teater och svenska skådespelare frän Gustav III till våra dagar, del I, Bonnier, Stockholm 1917, pp. 5-6.

5 Skuncke, op. cit., p. 193.

6 Barbro Stribolt, "Louis Jean Deprez. An Introduction" in Gustavian Opera. Swedish Opera, Dance and Theatre 1771-1809, Almqvist and Wiksell Trycker, Uppsala 1991, pp. 123-5.

7 It is worth noting that the Russian opera under Catherine the Great was mainly influenced by Italian composers, conductors and musicians.

8 Skuncke, op. cit., pp. 204-6; Nordensvan, op. cit., pp. 14-15. Just as with the Swedish drama theater, the Russian drama theater of that period was mainly influenced by the French.

9 Marie-Christine Skuncke, "Sweden and European drama 1771-1796. A presentation of cross-cultural contacts" in Gustavian Opera, op. cit., p. 151.

10 Likewise, the influence of French drama as well as national history was also characteristic of Catherine's plays.

11 Erik Lönnroth, "Prologue" in Gustavian Opera, op. cit., p. 18.

12 Marie-Christine Skuncke, "Gustav III och dramatiken" in Katarina den stora och Gustav III. Nationalmuseum 9 oktober 1998 - 28 februari 1999, Magnus Olausson, ed., Nationalmuseum, Helsingborg 1998, p. 279.

13 Nikolai Evreinov, "O rysskom teatre ne-rysskogo proishozhdeniya i ne-rysskogo yklada" in Teatral'nye novatsii (Николай Евреинов, "О русском театре нерусского происхождения и не-русского уклада" в Театральные новации), Tyretia strazha, Petrograd 1922.

14 Evreinov, op. cit., p. 42.

15 Evreinov, op. cit., p. 49.

16 The overview of the Russian eighteenth century theatre was based on Evreinov, op. cit. and also on Vsevolod Vsevolodskiy-Gerngross, Istoria rysskogo teatra, I (Всеволод Всеволодский-Гернгросс, История русского театра I), Moscow, Leningrad 1929.

17 The overview of the century Hermitage Theatre is based on Dmitry Varygin, Irina Etoeva, Yermitazhniy teatr (Дмитрий Варыгин, Ирина Етоева, Эрмитажныци meamp), Gosydarstvennyi Ermitazh, Slavia, St. Petersburg 2005.

18 Istoria rysskogo dramaticheskogo teatra ot ego istokov do kontsa XX veka (История русского драматического театра от его истоков до кониа ХХ века), GITIS, Moscow 2009, p. 54.

19 Lurana Donnels O'Malley, The Dramatic Works of Catherine the Great. Theater and Politics in Eighteenth-Century Russia, Ashgate Publishing Company, Farnham 2006, p. 12.

20 Skuncke, “Gustav III och dramatiken”, op. cit., p. 279.

21 Like Gustav III, Catherine the Great had some assistants who helped edit her plays. 
